\title{
Factors affecting seasonal forecast use in Arizona water management: a case study of the 1997-98 El Niño
}

\author{
Thomas C. Pagano*, Holly C. Hartmann, Soroosh Sorooshian \\ Department of Hydrology and Water Resources, The University of Arizona, Tucson, Arizona 85721, USA
}

\begin{abstract}
The 1997-98 El Niño was exceptional, not only because of its magnitude, but also because of the visibility and use of its forecasts. The 3 to 9 mo advance warning of a wet winter with potential flooding in the US Southwest, easily accessible by water management agencies, was unprecedented. Insights about use of this information in operational water management decision processes were developed through a series of semi-structured in-depth interviews with key personnel from a broad array of agencies responsible for emergency management and water supply, with jurisdictions ranging from urban to rural and local to regional. Interviews investigated where information was acquired, how it was interpreted and how it was incorporated into specific decisions and actions. In addition, technical and institutional barriers to forecast use are explored. Study findings emphasize (1) the need for special handling of tailored forecast products on a regional scale, (2) the need for systematic regional forecast evaluation and (3) the potential for climate information to directly affect water management decisions through integrating climate forecasts into water supply outlooks where appropriate.
\end{abstract}

KEY WORDS: Seasonal forecast use $\cdot$ Water resources $\cdot$ El Niño/Southern Oscillation

\section{INTRODUCTION}

Effective management of water supplies is becoming increasingly important in the semi-arid US Southwest, as a result of rapid population growth. Because development of new supplies has become prohibitively expensive, it is critical to manage the already overcommitted surface-water supplies with increasing sophistication. Regulations attempting to reduce pumping of non-renewable groundwater may increase supply vulnerability to interannual climate variability. While avoidance of water supply shortages is a primary water management objective, flooding is also troublesome. Arizona has experienced a resurgence of flooding since the 1970s with winter flooding in 1972, 1978, 1983 and 1993. Damage from the October 1983

*E-mail: pagano@hwr.arizona.edu and winter 1993 floods was estimated at over \$225 million and \$300 million, respectively (US Army Corps of Engineers 1994). Flood events are the most frequent cause of emergency management actions in Arizona (Confidential study participant, Arizona Division of Emergency Management, pers. comm., 1998).

Seasonal climate forecasts have the potential to improve water management response to interannual variability and to reduce flood damages. The utility of seasonal forecasts for water management has long been recognized (Changnon \& Vonnhame 1986), although they often play only a marginal role in realworld decision-making (Changnon 1990, Sonka et al. 1992, Pulwarty \& Redmond 1997, Callahan et al. 2000, Pulwarty \& Melis unpubl.). The 1997-98 El Niño event represents a turning point in seasonal forecasting and water management in the US Southwest. In 1997, climate forecasts of a large El Niño and its potentially devastating impacts were widely distributed and 
highly visible. Several water management agencies perceived that the climate forecasts crossed the threshold of utility and incorporated them into operational decisions, providing a rare opportunity to investigate how forecasts traveled through various distribution channels to their users and how they were applied in practice. Due to the relatively strong signal of El Niño in the US Southwest, with several examples of exceptional floods, and the paramount importance of water management, the region's capacity to use climate forecasts may be greater than elsewhere. This study seeks to clarify how water management agencies in Arizona utilized the advance warning of the 1997-98 El Niño, with the objective of assisting forecasters in more effectively serving user communities.

\section{BACKGROUND}

\subsection{El Niño teleconnections with Arizona hydroclimatology}

El Niño's effects on Arizona hydroclimatology are documented by an extensive body of literature (Cayan \& Peterson 1989, Redmond \& Koch 1991, Kahya \& Dracup 1993, Cayan 1996, Woodhouse 1997). El Niño conditions favor enhanced precipitation from fall to spring, with the signal in Arizona being among the strongest in the contiguous US. Also, in September, when tropical Pacific hurricanes are most likely to hook northward, tropical cyclones are approximately $50 \%$ more frequent during El Niño than other years (Webb \& Betancourt 1992); hurricanes have affected Arizona and California only during the strongest El Niño events (e.g. Nora in 1997, Octave in 1983; Andrade \& Sellers 1988). However, El Niño-precipitation relationships are neither linear nor deterministic; Redmond \& Koch (1991) show the wettest winter on record in Arizona was not an El Niño period and the second strongest El Niño produced near normal precipitation. While preliminary evidence suggests that, at least in the Salt River region, enhanced precipitation is due to increased storm intensity (Cayan \& Webb 1992), research is needed to identify other precipitation qualities influenced by El Niño (e.g. number of rainy days).

The signal of enhanced and delayed streamflow is clearer than the precipitation signal, reflecting snowpack enhancement. Extreme floods have occurred in Arizona during El Niño periods (e.g. 1941, 1983, 1993), but the limited number of El Niño events, combined with the rare nature of floods, makes it difficult to establish robust relationships. Most of the biggest floods on major Arizona rivers have occurred during El Niño or within 6 mo of its end (Cayan \& Webb 1992).
Large Arizona winter floods occur almost exclusively when the 5 yr running mean of the Southern Oscillation Index (SOI) is negative, indicating persistent El Niño conditions (Ely 1997), although exceptions appear during brief strong El Niño events amidst longer La Niña events (e.g. 1957, 1976). Webb \& Betancourt (1992) show that on the Santa Cruz River, flooding is more intense during El Niño events, but not more frequent. To further complicate matters, flooding events have occurred during years with near-normal seasonal streamflow totals. However, the most notable recent floods have occurred during El Niño years (1983 and 1993). The 1993 floods were the most expensive in Arizona history, and are easily recalled by water managers.

\subsection{Arizona water management}

Extensive management is required to capture, store and distribute the limited surface waters that provide roughly half of Arizona's water supply. While water management has common themes, methods and regulations, the agencies involved are highly varied and diversified. Some communities are served by extensive water management and flood control structures (e.g. lower Colorado and Salt watersheds), whereas others reside downstream of completely unimpeded flow (e.g. San Pedro and upper Gila watersheds). Agencies that manipulate surface water supplies typically operate under long-standing agreements with other users, often arising from legal proceedings. Reservoir storage is but one form of protection against flood emergencies; structural barriers, riverbank cementation, behavioral controls (e.g. floodplain building restrictions) and flood-warning systems (to assist National Weather Service [NWS] flood warning issuance) are managed by Flood Control Districts (FCDs). In flood emergencies, the FCDs, the NWS, and water suppliers cooperate with Emergency Management Agencies (EMAs) at various levels of jurisdiction; the EMAs serve as central coordinators of activities that may involve many other groups (e.g. Department of Transportation, Red Cross). EMAs also engage in preparedness (to ensure response effectiveness), and mitigation (to reduce disaster threats before they occur). However, floods are only one of many emergencies that concern EMAs, including hazardous materials, domestic terrorism, and nuclear disasters.

To support water-management activities across the US Southwest, the NWS Colorado Basin River Forecast Center, jointly with the Natural Resources Conservation Service and (for select basins) Salt River Project (SRP), issue Water Supply Outlooks (WSOs). These are deterministic forecasts of cumulative streamflow vol- 
ume during a specified spring melt season (January to April in Arizona, later for more northern basins) (Hartmann et al. 2002 this issue). They have been issued since the 1940s and play a significant role in the operations of several water-management agencies, including reservoir regulation for seasonal flood control (Burke \& Stevens 1984) and water allocation to users in times of shortage (Glantz 1982); their use is, in some cases, required by law.

\subsection{The 1997-98 El Niño in Arizona}

To fully understand the role of climate information and forecasts in agency operations it is crucial to appreciate situational details (Stern \& Easterling 1999). Antecedent conditions and the unfolding of the forecasts and impacts associated with a climate event influence how users interpret the event, interpret information about it and make their decisions. Among the earliest forecast products identifying potential El Niño impacts in the Southwest was the NWS Climate Prediction Center (CPC) July 1997 special summary (CPC 1997a). It contained reviews of historic data and modeling studies related to potential El Niño impacts on Southwest US precipitation. It also provided official CPC seasonal climate outlooks and a qualitative forecast that the region's persistent drought would be relieved by winter precipitation. Streamflow impacts were not mentioned.

The first perceived regional impacts of the 1997-98 El Niño occurred in September, as remnants of Hurricane Nora passed over Arizona. On September 25, Nora caused flooding near Yuma and several smaller cities west of Phoenix. Parts of southwest Arizona received a year's worth of rainfall in $24 \mathrm{~h}$ (1 to 4 inches [2.5 to $10.2 \mathrm{~cm}$ ]) and a state $24 \mathrm{~h}$ rainfall record was set (11.97 inches [30.4 cm] in the Harquahala Mountains) (Waters 1997); crop damage was estimated at $\$ 300$ million (Rappaport 1997). Weather and flood warnings related to Nora activated local and statewide emergency response mechanisms. Concern focused on eastern Arizona, where storms 3 to $4 \mathrm{~d}$ prior had saturated the soil, making additional rainfall potentially disastrous. Anticipated rainfall from Nora in central and southeast Arizona did not materialize because the actual storm path was hundreds of miles west of the forecast path, and the storm traveled relatively quickly. There was poor perception of forecast quality in Arizona's major cities, where negligible precipitation fell. Subsequently, the media questioned if the forecasts for El Niño were as poor as those for Nora. Yet, Nora did cause considerable damage in western Arizona; there, the perception of Nora forecasts was more favorable and lent credibility to forecasts for possibly extreme winter precipitation. Shortly before Nora, and not long afterwards, several regional scientific meetings and agency briefings occurred that included presentation of information about El Niño (see Section 4.1). Many informational products about El Niño also became available at this time, including the November 1997 CPC special summary (CPC 1997b) and a multitude of Internet sites.

While December was very wet in central and southeast Arizona, at this time the upper Colorado River basin had cumulative water year precipitation totals falling within the driest tercile of the 1961-90 record. On January 1, the NWS issued WSOs predicting streamflow to be far above normal throughout Arizona (e.g. 182 and $365 \%$ of median for the Salt-Verde and Gila Rivers, respectively), but only near normal flowing into Lake Powell. January was extremely dry across Arizona. Among some agencies and in the media, there was increasing doubt about climate forecast accuracy and whether El Niño was going to 'happen' in Arizona. Streamflow forecasts issued February 1 reflected low snowpack accumulations and predicted seasonal flows more near normal. February and March were exceptionally wet across Arizona. Media attention on El Niño became pervasive and March 1 streamflow forecasts returned to predictions of above-normal flows.

After a cool, relatively dry spring, water year precipitation totals before the summer monsoon were marginally within the wettest tercile of the 1960-91 historical record. Forecasts for above-normal flows in Arizona rivers were generally correct, with observations falling within the forecast 10 to $90 \%$ error bands for all lead times and almost all locations. However, less flooding occurred than during normal years, with only Hurricane Nora producing emergency flood situations.

\section{METHODOLOGY}

Many anthropological research tools, quantitative and qualitative, exist to characterize use of climate information and forecasts by resource management agencies, as well as the motivations and decisionmaking processes behind agency actions. Due to the diverse and evolving nature of the institutions, climate events, and forecasts, this study relies on qualitative analysis, extended semi-structured interviews with key agency personnel and selective sampling. The essential limitation of this approach, an inability to develop quantitative relationships (Whyte 1977, Mohr $1982,1999)$, is nonproblematic; the goal is to identify and understand strategic institutional decisions in light of climate variability and forecasts, not to develop econometric or quantitative decision models. 
Advantages derive largely from a focus on contextual details and understanding processes. In contrast to quantitative approaches, qualitative analysis of extended interviews brings to light the complexitiespredicaments, tradeoffs, strategies-behind what otherwise would be simply statistical outcomes (Schoenberger 1991). Further, this focus aids the valid transfer of results to other situations (e.g. other regions, agencies, climate events), by enabling identification of commonalities between what are essentially case studies and the new situation (Mohr 1999). In contrast, reliance on sampling strategies and standardized questionnaires (e.g. Changnon 2000) to justify transferring results to other situations can be misplaced. The diversity and continuing evolution of conditioning variables (e.g. institutional objectives, mandates, resources; prior climate events and consequences; salient climate signals; forecast skill; conditions immediately preceding climate events) confound determination of a useful encompassing population and sufficient random sampling (Mohr 1999). Finally, the approach concurrently educates study participants (Whyte 1977), as supported by the National Research Council (Stern \& Easterling 1999).

Agencies selected for participation covered local, state and federal jurisdictions within Arizona and had responsibility for managing water supplies or flood hazards. Agencies and key personnel were identified based on an understanding of Arizona's watermanagement milieu and recommendations by others, including the solicited agencies. Not all contacted agencies chose to participate; 14 declined, although 4 did consent to a single 5-10 min interview. Reasons given for non-cooperation included perceived lack of El Niño impacts or response options, disinterest in the effort required and suspicion of non-confidentiality or motives. Sixteen agencies were interviewed at length: the Upper and Lower Colorado River Districts of the US Bureau of Reclamation (BOR), Arizona Department of Water Resources, Arizona Division of Emergency Management (ADEM), Office of the Governor, Salt River Project, Gila River Water Commission, Santa Cruz Active Management Area, Maricopa and Pima County FCDs, 5 county-level EMAs and Tucson Water.

Effective interviewing strategies (Whyte 1977, Schoenberger 1991, Bernard 1994) were implemented to ensure accurate results. Between May 1998 and January 1999 (mostly during summer 1998), each participant engaged in a series of interviews, consisting of up to 3 sessions lasting 1 to $5 \mathrm{~h}$ each, followed by an opportunity to review statements and provide corrections, clarification and elaboration. Prior to the first interview, participants received an 11 page interview guide consisting of information about the study, discussion questions and several relevant climate prod- ucts. The guide was developed with the assistance of the University of Arizona Bureau of Applied Research in Anthropology (BARA) following standard practices (Bernard 1994, Rubin \& Rubin 1995); BARA also provided interview technique training, including field experience during related climate vulnerability assessment surveys. The same individual, educated in hydroclimatology and water resources, performed background research, solicited agency participation and conducted all interviews. Interview notes and taperecordings are archived and available consistent with confidentiality agreements.

Effective interviews produce an interactive dialogue between interviewer and participant. Not all topics get covered in the same way; that some participants volunteered information should not be construed as meaning others did not concur. In some cases, participants reported on actions and rationales of other agencies; members of the water-management community, particularly EMAs, often know what their colleagues are doing and why. Thus, some findings refer to a group larger than the agencies granting interviews. Finally, information derived elsewhere (meeting notes, reports, intra-agency communications, press releases, media accounts, informal discussions with other water management agencies, hydroclimatic data) was used to corroborate interviews and provide additional perspective. To reinforce that results are not intended to be statistically generalized to other populations, interview responses are presented only in relative terms: none, one, few, some, many, most, almost all, all.

\section{RESULTS AND DISCUSSION}

\subsection{Sources of information}

Table 1 lists the sources of information used by the water-management agencies during the 1997-98 El Niño event, along with summaries of their advantages and disadvantages as reported by the agencies.

\subsubsection{National Weather Service briefings}

All participants located in cities with NWS Weather Forecast Offices (WFOs) had contact with meteorologists in obtaining information about El Niño. These agencies had established contacts with the WFOs from previous weather-related events (i.e. flash flooding), and the NWS was active in a series of agency briefings organized by local and state EMAs. Large water providers also participated in several of these meetings and provided information about reservoir levels and estimates of potential for uncontrolled releases. 
Table 1. Sources of information summary

\begin{tabular}{|c|c|c|}
\hline Source & Advantages & Disadvantages \\
\hline NWS & Trusted expertise. Established contacts with agencies & $\begin{array}{l}\text { Limited resources. Has lesser involve- } \\
\text { ment in remote communities }\end{array}$ \\
\hline Agency briefings & Good for inter-/intra-agency coordination. Interactive & $\begin{array}{l}\text { Infrequent. Occasionally difficult to } \\
\text { understand if non-interactive }\end{array}$ \\
\hline In-house research & Integrates well into operations. High confidence in findings & $\begin{array}{l}\text { Not all agencies have sufficient } \\
\text { resources, capacity to conduct }\end{array}$ \\
\hline Internet & $\begin{array}{l}\text { Wealth of data for conducting independent in-house research. } \\
\text { Participatory, active }\end{array}$ & $\begin{array}{l}\text { Information overload. Unregulated. } \\
\text { Some agencies lack access. Time } \\
\text { consuming }\end{array}$ \\
\hline Public media & Understandable, timely, pervasive & Alarmist, superficial, low skill \\
\hline Universities & Extensive expertise, resources & $\begin{array}{l}\text { Difficult to approach and utilize. Lack } \\
\text { central contact }\end{array}$ \\
\hline
\end{tabular}

Materials presented at these briefings typically described El Niño, provided the latest Pacific Ocean status, and reviewed historical impacts of El Niño in the Southwest. National Oceanic and Atmospheric Administration (NOAA) products (including those from the NWS, such as the CPC outlooks) were frequently presented along with specially prepared historical data specific to the city in which the meeting was held. Some participants located in cities where the briefings did not occur still reported having contact with the NWS, although their contact was not as frequent or indepth. ADEM and the Phoenix WFO were involved in at least 10 briefings across the state in communities lacking WFOs, as part of the assistance provided by $\mathrm{ADEM}$ at the request of various counties. Lack of interaction with WFOs may stem from not knowing NWS offices could provide unique resources; one participant did not distinguish between public (NWS) and private forecast sources (The Weather Channel).

\subsubsection{Inter- and intra-agency communication}

All participants reported that informal gatherings of personnel within and between agencies were useful for exchanging information, coordinating efforts, and helping agencies prepare. Occasionally, personnel assigned to gather information, track events and brief others on findings and predictions had positions related to meteorology or climate, but often their responsibility derived from personal interest in the subject. In September 1997 the Arizona Governor's Office coordinated activities of primarily state agencies to prepare for Hurricane Nora. This was transformed into an 'El Niño Task Force' that held monthly meetings before and throughout the winter to brainstorm possible preparations, provide updates to the governor and disseminate information through an Internet web- site. Interactively, members crafted scenarios with possibilities of occurrence and potential responses. A Phoenix WFO meteorologist informally recommended that major structural activity was unnecessary; it would be more efficient to prepare for and respond to events as they materialized. Participating agencies found this translation of CPC forecast products into operationally directed statements invaluable. A few agencies participating in this study also attended a September 1997 regional climate vulnerability workshop hosted by the US Global Change Research Program and the University of Arizona, which addressed El Niño. One agency considered the presentations informative and still refers to the materials distributed. Another reported that many details were too technical, although they still benefited from opportunities to interact and establish contacts with scientists and other agencies.

\subsubsection{In-house research}

All participants that considered committing significant resources to proactive measures supplemented information gathering with in-house research. For example, the BOR Lower Colorado River District's research showed that streamflow from the upper Colorado River basin did not have a strong or consistent enough El Niño signal for the agency to commit to serious action. The BOR Upper Colorado River District's research revealed underforecast bias in WSOs during strong El Niño years. While individual agencies may not have the sophisticated research tools available to climate forecasters, the confidence agencies placed in their own research, no matter how elementary, was always greater than for external products. Although one water provider joked that they only consider external forecasts and information consistent with their internal findings and beliefs, the statement captures a 
running theme among participant responses. Conservative water managers are reluctant to change operations without a thorough understanding of and high confidence in supporting information.

\subsubsection{The Internet}

At the NWS/EMA meetings, addresses of official websites pertaining to El Niño were provided. Most participants surveyed used the Internet and found it very useful in gathering information. Users considered the Internet an active information gathering tool, compared to the passive nature of public media; however, unguided searching was seen as ineffective time management. Sites visited included NOAA and NWS sites with technical El Niño information and forecast products, as well as sites providing more regional information (e.g. Western Regional Climate Center). Media sites (e.g. The Weather Channel) provided more generic qualitative information about El Niño. A few participants volunteered that they were more inclined to believe information presented on the Internet than on television, perceiving it to be better researched and more in-depth.

\subsubsection{The public media}

Media coverage of El Niño had both positive and negative aspects. Almost all EMAs first heard about the event and its extreme potential from the general media. Widespread media coverage also increased public awareness about flooding and preparedness. Public anxiety caused by alarmist media predictions caused EMAs to seek out more information to assess the credibility of such forecasts. As more information was obtained, EMAs recognized that media predictions were unrealistic and shifted reliance to the NWS and/or the Internet. While increased public awareness was considered beneficial, EMAs often found themselves trying to correct misconceptions and ease citizen fears about dire media predictions. The few participants with little access to alternative information sources felt that qualitative media forecasts were sufficient to determine preparation strategies; however, when asked to describe El Niño, they had only a vague, and in one case completely inaccurate, understanding.

\subsubsection{Universities}

Few agencies reported having extensive contact with university scientists in obtaining El Niño information; one user had recently left a university setting after many years, while another had long-standing relationships with local institutions. One participant stated that if the NWS had not been as active or early in providing information, he would have approached the local university. Contact with the NWS was preferred by users with no previous university contacts, because, as one user said, 'There's a perception of inaccessibility... It's a huge resource that's not easily tapped.'

\subsection{Interpretation of information}

None of the individuals encountered used CPC probability values directly in their decision-making processes. Instead, those probabilities were translated into simple qualitative likelihoods (e.g. wetter than normal winter with an increased chance of flooding). Universally, the farther information traveled from CPC products before reaching the user, the less probabilistic it became. However, all participants that prepared for the 1997-98 El Niño first translated forecasts into quantitative estimates of precipitation or streamflow amounts, even if these quantities were not explicitly incorporated into specific decisions; this translation was made individually on an ad hoc basis, or provided by other agencies, in-house research, or informally by the NWS. The wide range of expectations, shown in Table 2, represents both accurate translation of CPC products to local conditions and user misunderstanding about the meaning of forecasts and products. For example, almost all users who had seen the CPC climate outlooks misinterpreted their large probability anomalies as forecasts for extremely high precipitation. In all cases, translations of climate forecasts into specific quantities relied on subjective analyses that could not be explicitly described or reproduced by participants.

\subsection{Agency response}

Agency responses must be understood in the context of the low storage status of Arizona reservoirs prior to

Table 2. Forecasts versus agency expectations

What the climate forecasts expressed:

Approximately a $50 \%$ probability of seasonal precipitation totals being in the wettest $33 \%$ of record (1961-90)

What agencies prepared for:

Business as usual

$5-10 \%$ above normal precipitation

$50 \%$ above normal precipitation

$100 \%$ above normal precipitation

Flooding equivalent to 1992-93 flood

Flooding worse than 1992-93 flood 
the winter, resulting from extended dry conditions occurring since the 1992-93 winter floods; low reservoir levels also provided a buffer against potential flooding. This differed from California, where devastating floods during the 1996-97 winter created critical need to quickly repair damaged structures to withstand consecutive years of flooding. Arizona conditions also differed from those in the upper Colorado River basin, where wet years throughout the 1990s caused mainstem reservoirs to be the most full since the 1983 floods.

Actions taken by agencies in preparation for the 1997-98 winter are described in further detail by Pagano et al. $(2000 a, b)$. EMA actions, shown in Table 3, involved focusing internal attention on floods rather than other types of threats (e.g. earthquakes), reviewing flood response plans and improving interagency communication. Almost all field activities occurred on a community level, encouraged by state agency interest and, to a lesser extent, public awareness. Some agencies volunteered that they were reluctant to dramatically change operations, saying they attempt to constantly maintain maximal preparedness, with or without El Niño. Agencies avoided major structural activities; most considered it more efficient to respond to individual storms rather than attempt to broadly reduce flood risk.

The diverse range of water-provider actions, summarized in Table 4, reflects the complicated nature of water management, whereby water providers have different capacities and options to act on seasonal forecasts. Agencies' preparatory activities were based on numerous factors, including reservoir status, legal constraints and management flexibility, among others.
Only agencies that manage both surface and groundwater (i.e. SRP and Mexico's Comision Nacional del Agua) were able to realize financial gain from forecast use. BOR used forecasts to enhance flood protection, without direct financial benefit. All others were unaffected by the forecasts and engaged in business as usual (i.e. Gila River Commission, groundwater providers).

\subsection{Forecast characteristics affecting use}

While all participants reported satisfaction with the quantity and quality of information they received, most provided insights on why certain products were more useful than others. Some participants also reviewed specific forecast products (e.g. CPC seasonal outlooks) and provided recommendations on how they could be improved. This section reviews some issues users face while trying to incorporate forecasts into operations.

Climate-forecast producers should recognize that institutional factors can limit use of even the most skilled and user-friendly forecasts. Some agencies in the greater water-management community consider themselves insensitive to climate variability and forecasts. Others lack flexibility, resulting from internal barriers (e.g. reluctance to change operations, lack of resources to prepare for an oncoming event, perceiving use of imperfect forecasts as exposing them to unnecessary risk) or imposed limitations (e.g. legal constraints). These institutional factors are outside the control of forecast agencies and detailed elsewhere (Pagano et al. 2000a,b).

Table 3. Extreme event management agency response summary

\begin{tabular}{|c|c|c|c|}
\hline Agency & Action & Reasoning & Result \\
\hline $\begin{array}{l}\text { Governor's El Niño } \\
\text { task force }\end{array}$ & $\begin{array}{l}\text { State agency organization. } \\
\text { Deepening of Gila River crossing } \\
\text { at Interstate } 10\end{array}$ & $\begin{array}{l}\text { Strong public interest. } \\
\text { Hurricane Nora damage }\end{array}$ & No flooding \\
\hline $\begin{array}{l}\text { Arizona Division of } \\
\text { Emergency Manage- } \\
\text { ment (ADEM) }\end{array}$ & $\begin{array}{l}\text { Joint briefings tour with NWS. } \\
\text { Support to Arizona County EMAs, mainly } \\
\text { for Lower Colorado mainstem, Yuma }\end{array}$ & $\begin{array}{l}\text { Precedent for flooding on major rivers } \\
\text { during El Niño }\end{array}$ & No flooding \\
\hline $\begin{array}{l}\text { Large urban emer- } \\
\text { gency management }\end{array}$ & $\begin{array}{l}\text { Agency briefings. Coordination. } \\
\text { Enhanced focus on flooding for yearly } \\
\text { preparations. Equipment purchase }\end{array}$ & See ADEM & No flooding \\
\hline $\begin{array}{l}\text { Other emergency } \\
\text { management }\end{array}$ & $\begin{array}{l}\text { Awareness. Double-checking and } \\
\text { augmenting supplies }\end{array}$ & $\begin{array}{l}\text { See ADEM. Desire to act but lack of } \\
\text { resources prevented serious action }\end{array}$ & No flooding \\
\hline $\begin{array}{l}\text { Flood control } \\
\text { district A }\end{array}$ & $\begin{array}{l}\text { Including more agencies in yearly } \\
\text { planning. Prepared for large river flooding } \\
\text { instead of flash flooding. Maintain, repair } \\
\text { ALERT system }\end{array}$ & $\begin{array}{l}\text { In-house research showed El Niño caused } \\
\text { major rivers to flood, not minor washes }\end{array}$ & No flooding \\
\hline $\begin{array}{l}\text { Flood control } \\
\text { district B }\end{array}$ & $\begin{array}{l}\text { Business as usual. Participation in } \\
\text { emergency management briefings }\end{array}$ & $\begin{array}{l}\text { Preparedness is equal for all events, not } \\
\text { only El Niño years. Budgetary constraints }\end{array}$ & No flooding \\
\hline
\end{tabular}


Table 4. Water-provider agency response summary

\begin{tabular}{|c|c|c|c|}
\hline Agency & Action & Reasoning & Result \\
\hline $\begin{array}{l}\text { Primarily groundwater } \\
\text { providers }\end{array}$ & $\begin{array}{l}\text { Business as usual. Protect pumping } \\
\text { equipment }\end{array}$ & $\begin{array}{l}\text { Groundwater supply not strongly } \\
\text { affected by interannual variability }\end{array}$ & $\begin{array}{l}\text { Recharge indeterminable. } \\
\text { Flood damage did not } \\
\text { occur }\end{array}$ \\
\hline Gila River Commission & Business as usual & $\begin{array}{l}\text { Adequate storage for potential } \\
\text { flood already existed. Legal } \\
\text { constraints }\end{array}$ & $\begin{array}{l}\text { Streamflow not } \\
\text { exceptional. Dry condi- } \\
\text { tions persist }\end{array}$ \\
\hline Salt River Project & $\begin{array}{l}\text { Reduction of groundwater pumping } \\
\text { by } 41000 \text { acre-feet (ac-ft) }(22 \%)_{i} \\
\text { water replaced with surface water } \\
\text { from Verde basin reservoirs }\end{array}$ & $\begin{array}{l}\text { Small storage capacity on Verde } \\
\text { watershed ( } 315000 \text { ac-ft). Past } \\
\text { history of flooding. Adequate } \\
\text { storage in Salt River reservoirs. } \\
\text { Confidence of in-house research }\end{array}$ & $\begin{array}{l}\text { Verde reservoirs fill, } \\
\text { with minimal spill } \\
\text { (<52 } 000 \text { ac-ft). Ground- } \\
\text { water pumping costs, } \\
\$ 1 \text { million, avoided. } \\
\$ 4-5 \text { million loss, } \\
\text { had forecast been wrong. }\end{array}$ \\
\hline $\begin{array}{l}\text { Bureau of Reclamation } \\
\text { (BOR) Upper Colorado } \\
\text { River District }\end{array}$ & $\begin{array}{l}\text { Additional releases to provide } \\
4 \times 10^{6} \text { ac-ft storage in Lake } \\
\text { Powell; exceeds available } \\
\text { storage during } 1983 \text { floods } \\
\text { by } 2 \times 10^{6} \text { ac-ft }\end{array}$ & $\begin{array}{l}\text { Poor performance of Water Supply } \\
\text { Outlooks during } 1983\left(8 \times 10^{6} \mathrm{ac}-\mathrm{ft}\right. \\
\left.\text { forecast, } 15 \times 10^{6} \mathrm{ac}-\mathrm{ft} \text { observed }\right) \\
\text { and } 1995\left(6 \times 10^{6} \mathrm{ac}-\mathrm{ft} \text { forecast, }\right. \\
11.8 \times 10^{6} \mathrm{ac}-\mathrm{ft} \text { observed). In- } \\
\text { house research showing under- } \\
\text { forecast bias during El Niño }\end{array}$ & $\begin{array}{l}\text { Hydrologic forecasts } \\
\text { did underestimate } \\
\text { streamflow by } 2 \times 10^{6} \\
\text { ac-ft }(\sim 25 \%) \text {. No uncon- } \\
\text { trolled reservoir releases }\end{array}$ \\
\hline $\begin{array}{l}\text { BOR Lower Colorado } \\
\text { River District }\end{array}$ & $\begin{array}{l}\text { Receive water from Lake Powell. } \\
\text { Additional flood control releases } \\
\text { in April } 1998\end{array}$ & $\begin{array}{l}\text { Equilibration of reservoir levels } \\
\text { with Lake Powell. Avoid } \\
\text { repetition of } 1983 \text { floods }\end{array}$ & $\begin{array}{l}\text { See BOR Upper Colorado } \\
\text { River District }\end{array}$ \\
\hline $\begin{array}{l}\text { Comision Nacional del } \\
\text { Agua (CNA), Mexico }\end{array}$ & $\begin{array}{l}\text { Reduce groundwater pumping } \\
200000 \text { acre-feet. Utilize } \\
\text { excess flows }\end{array}$ & $\begin{array}{l}\text { 1996-97 high flows, Colorado } \\
\text { River reservoirs at full status, } \\
\text { and declaration of 1997-98 } \\
\text { water supply surplus }\end{array}$ & $\begin{array}{l}1.7 \times 10^{6} \text { ac-ft utilized, } \\
\text { remainder }\left(2.3 \times 10^{6} \mathrm{ac}-\mathrm{ft}\right) \\
\text { flowed to Gulf of } \\
\text { California unused }\end{array}$ \\
\hline
\end{tabular}

\subsubsection{Accessibility}

The visibility of most 1997-98 El Niño-related forecasts was exemplary, partly because they were aggressively disseminated by various agencies. An exception, for unknown reasons, was the June 1997 CPC special summary (CPC 1997a); while specifically addressing potential hydrologic impacts of El Niño in the Southwest, few participants knew of it. The subsequent special summary (CPC 1997b) received much more attention; while it addressed potential implications of El Niño in broader context, the timing of its issuance was consistent with growing awareness about El Niño. All participants received some kind of climate information or forecast prior to the event, although the quality of information depended on its source. Information quality was greatly enhanced when ongoing relationships existed, or were developed, directly between forecast producers and users. Users without access to personal, clear interpretation of climate information and forecasts relied instead on less sophisticated, sometimes less accurate, but easily understandable sources such as the media. Although they may be highly vulnerable to climate variability, agencies with few resources may not actively seek out climate information and may access only the most visible forecasts. Engaging these users more effectively requires regional efforts, with a focus on efficient access, and succinct yet tailored communication available from a credible central source.

\subsubsection{Interpretability}

CPC seasonal climate outlooks forecast shifts in probability distributions. In the words of one participant, 'So many people were confused about what they meant.' The tendency by those unfamiliar with the forecasts was to translate the probability anomalies into expected quantities. For example, where large probability shifts were indicated, users anticipated greater precipitation totals than in those locations with smaller shifts. This improper interpretation implied that Arizona would receive absolutely or proportionately more precipitation than southern California (which normally receives more precipitation than Arizona). Correctly interpreted, the forecasts indicated only a greater likelihood of Arizona precipitation being in the 'above-normal' category and that forecasts for 
California had less confidence than for Arizona. Technical jargon routinely prevents agencies from extracting useful information from data provided; simplified but ambiguous terms (e.g. 'above normal precipitation') are also misleading. While CPC outlooks have precise definitions of what 'normal' indicates, some users (especially EMAs) perceive 'normal' as meaning 'free of extreme events', which can lead to confusion about forecast accuracy. Simple forecasts can be more precise if forecasters are aware of individual user needs.

\subsubsection{Credibility}

Almost all agencies surveyed were unfamiliar with CPC seasonal outlooks before the 1997-98 El Niño event; their assessments of forecast accuracy were based on consistency among forecast statements from authorities and with findings of in-house research, and memory of previous flood events during El Niño years. The El Niño event's magnitude allowed all agencies to overlook climate forecast details and accept at least the qualitative prediction for a wetter than normal winter with a chance of flooding. This will not be the case, however, in moderate or weak El Niño years.

BOR expressed that routine use of climate forecasts in operations requires proof of forecast accuracy. Within the greater water management community, agencies seek to minimize potential 'surprise', either from climate or from repercussions when forecasts prove inaccurate. Agencies may have a fair estimate of potential surprise from climate, but not from hydroclimatic forecast error. When asked about perceived accuracy of climate forecasts, participant estimates were high (60 to $90 \%$ ), although almost all qualified their assessment as lacking quantitative basis; further, their expressions were not distinguished as being hit rates, improvement over climatology, or some other measure.

\subsubsection{Relevance}

One of the greatest challenges facing climate forecasters is providing relevant information that improves decisions. User information needs vary by sector, region and current conditions (e.g. reservoir status). The following aspects affected forecast relevance for at least some participants:

- Appropriate timing, of both lead-time and forecast period. Advance warning of the 1997-98 El Niño was adequate for all users, and the coverage periods of climate forecasts were relevant to managers concerned with total seasonal water supplies. However, only tenuous relationships exist between seasonal precipitation and short-term flooding events, making climate forecasts less relevant for EMAs.

- Different climate variables. While forecasts of hydrologic events and socioeconomic impacts are essential for determining appropriate levels of mitigation, the latter are difficult to quantify and outside current operational forecast focus. In contrast, 'raw' climate data (e.g. sea-surface temperatures) have limited usefulness. Because EMAs prepare for the worst case or focus on recurring events, increasingly detailed forecast products may not alter preparations. Reservoir managers, however, seek greater details in forecasts, especially during extreme reservoir storage conditions.

- Finer spatial resolution. In the Southwest, high elevation areas have unique climate interactions and contribute disproportionately to runoff and recharge. One agency expressed interest in forecasts that specifically target these areas; other agencies strongly affected by snowmelt runoff would benefit from such forecasts as well.

- Inclusion of historical analogs. Water-management agencies often decide preparations based on their own selection of historical analogs that seem consistent with their interpretation of climate forecasts, suggesting that forecasts can be made more relevant by identifying appropriate analogs. However, analog variability should be clearly communicated, to preclude users from anchoring expectations to a set of events that may not recur exactly as before (Nicholls 1999).

\section{CONCLUSIONS AND RECOMMENDATIONS}

Climate forecasts of the 1997-98 El Niño event accurately predicted enhanced winter precipitation, although the increase was not as dramatic as prior events (e.g. 1982, 1993) and only Hurricane Nora produced serious flooding. Users were exposed to climate forecasts through widespread media coverage, Internet access and special efforts at inter-agency communication. Accessibility, interpretability, credibility, and relevance were key characteristics of quality forecast products. Several unprecedented actions were taken by agencies, including the release of water from SRP and Colorado River reservoirs, focused training of EMAs and FCDs, and formation of task forces to address anticipated impacts. While no agencies made proactively inappropriate responses to El Niño, some missed opportunities for more effective response, primarily through inaction.

The process of incorporating climate information into water-management practices is an interactive, itera- 
tive process involving both forecast producers and users. Recommendations presented here focus on the climate-forecasting community, including both research and operational interests. Recommendations to the water-management community are presented elsewhere (Pagano et al. 2000a,b).

Recommendation 1. Provide regional special handling of forecasts and climate information. Water managers need additional information to be able to use details of current products, such as CPC outlooks. Some users sought additional information while others were limited to using outlooks as simple qualitative forecasts. Products generated at a national level cannot satisfy the needs of every region and every sector under every circumstance. It would be more effective for regional groups of scientists with awareness of sector vulnerabilities and management practices to focus on situations where agencies can make good use of the forecasts. For example, framing forecasts with antecedent conditions can help users appreciate the forecast's criticality. Regional forecasts should be developed with iterative, interactive user participation. Regular agency briefings and focus groups provide an effective method of forecast dissemination, especially when involving trusted channels of communication.

Recommendation 2. Thoroughly evaluate seasonal climate forecast accuracy. Assessment of the complete series of CPC climate outlooks would provide a quantitative basis for forecast credibility as well as identification of conditions during which outlooks have consistently performed well (or poorly). Although low forecast skill may reduce agency confidence in climate outlooks, at least those expectations would be realistic. Forecasts must be evaluated regionally and in a manner accurately reflecting agency vulnerabilities. For example, for an agency vulnerable to a single grossly incorrect forecast, simply computing forecast mean error or correlation is insufficient. Recognition that users have varying vulnerabilities and risk tolerance requires a diagnostic approach to forecast evaluation using joint and conditional distributions (Murphy \& Winkler 1992), rather than scalar measures.

Recommendation 3. Integrate climate forecasts into seasonal streamflow forecasts. Many water-supply agencies incorporate WSOs directly into operations. BOR is required by law to operate reservoirs using WSOs. However, current WSOs do not utilize climate information, with the exception of SOI for a limited number of watersheds; no WSOs utilize climate forecasts. Use of climate outlooks in water management can be increased by their transparent incorporation into operational hydrologic forecasts. Although the transfer of research products to the operational hydrologic forecasting community presents its own challenges (Hartmann et al. 2002), the climate forecasting community can assist the process. Foremost, current and historic CPC climate outlooks should be made available as digitized watershed-based quantities, consistent with requirements of hydrologic forecasting regression equations. More problematic is the creation of outlook time-series usable for calibrating the regression equations. Historical climate outlooks differ widely in their format and methodological basis, but hindcasting is also difficult because the outlooks are a subjective combination of multiple methodologies, including forecaster judgment.

Acknowledgements. We gratefully acknowledge the assistance of each study participant, BARA, and the Climate Assessment Project for the Southwest. Financial support was provided by NASA/EOS Grant \#OSSA-A/88, NOAA Office of Global Programs Grant \#NA86GP0061, NSF Graduate Research Traineeship, University of Arizona College of Engineering and Mines Dean's Fund, SRP Fellowship, and by SAHRA (Sustainability of semi-Arid Hydrology and Riparian Areas) under the STC program of the National Science Foundation, agreement No. EAR-9876800.

\section{LITERATURE CITED}

Andrade Jr ER, Sellers WD (1988) El Niño and its effect on precipitation in Arizona and western New Mexico. J Climatol 8(4):403-410

Bernard HR (1994) Research methods in anthropology: qualitative and quantitative approaches, 2nd edn. Sage Publications, Thousand Oaks, CA

Burke J, Stevens D (1984) The effects of runoff forecasting on Colorado River operations at Hoover Dam. In: Cassidy JJ, Lettenmaier DP (eds) A critical assessment of forecasting in water quality goals in western water resources management. American Water Resources Association (AWRA), Seattle, WA, p 47-53

Callahan B, Miles E, Fulharty D (1999) Policy implications of climate forecasting for water resources management in the Pacific Northwest. Policy Sci 32(3):269-293

Cayan DR (1996) Interannual climate variability and snowpack in the Western United States. J Clim 9(5):928-948

Cayan DR, Peterson DH (1989) The influence of North Pacific atmospheric circulation on streamflow in the West. Geophys Monogr 55:375-395

Cayan DR, Webb RH (1992) El Niño/Southern Oscillation and streamflow in the western United States. In: Diaz HF, Markaroff V (eds) El Niño: historical and paleoclimatic aspects of the southern oscillation. Cambridge University Press, Cambridge, p 29-68

Changnon D (2000) Who used and benefited from the El Niño forecasts? In: Changnon SA (ed) El Niño 1997-1998: the climate event of the century. Oxford University Press, New York, p 109-135

Changnon SA (1990) The dilemma of climatic and hydrologic forecasting for the Great Lakes. In: Hartmann HC, Donahue MJ (eds) Conference on The Great Lakes, Windsor, Ontario. The Great Lakes Commission, Ann Arbor, MI, p 13-25

Changnon SA, Vonnhame DR (1986) Use of climate predictions to decide a water management problem. Water Resour Bull 22(4):649-652

CPC (1997a) El Niño implications for the 1997 Southwest 
drought and fall/winter precipitation. Special Summary 97-2, Climate Prediction Center/National Oceanic and Atmospheric Administration, Camp Springs, MD

CPC (1997b) The 1997-98 El Niño: impacts and outlook. Special Summary 97-3, Climate Prediction Center/National Oceanic and Atmospheric Administration, Camp Springs, MD

Ely LL (1997) Response of extreme floods in the southwestern United States to climatic variations in the late Holocene. Geomorphology 19(3-4):175-201

Glantz MH (1982) Consequences and responsibilities in drought forecasting - the case of Yakima, 1977. Water Resour Res 18(1):3-13

Hartmann HC, Bales R, Sorooshian S (2002) Weather, climate, and hydrologic forecasting for the US Southwest: a survey. In: Yarnal B (ed) CLIMAS: Climate Assessment for the Southwest. CR SPECIAL 12. Clim Res 21:239-258

Kahya E, Dracup JA (1993) U.S. Streamflow patterns in relationship to the El Niño/Southern Oscillation. Water Resour Res 29(8):2491-2503

Mohr LB (1982) The reliability of the case study as a source of information. Discussion Paper No. 181, Institute of Public Policy Studies, The University of Michigan, Ann Arbor, MI

Mohr LB (1999) The qualitative method of impact analysis. Am J Eval 20(1):69-84

Murphy AH, Winkler RL (1992) Diagnostic verification of probability forecasts. Int J Forecast 7:435-455

Nicholls N (1999) Cognitive illusions, heuristics, and climate prediction. Bull Am Meteorol Soc 80(7):1385-1398

Pagano TC, Hartmann HC, Sorooshian S (2000a) Use of climate forecasts for water management in Arizona: a case study of the 1997-98 El Niño. J Am Water Resour Assoc (in press)

Pagano TC, Hartmann HC, Sorooshian S (2000b) Climate forecasts: a new tool for emergency management in the Southwestern US. Nat Hazards Obs 24(6):4

Submitted: May 11, 2000; Accepted: December 20, 2000
Pulwarty RS, Redmond KT (1997) Climate and salmon restoration in the Columbia River basin: the role and usability of seasonal forecasts. Bull Am Meteorol Soc 78(3):381-397

Rappaport EN (1997 Preliminary report: Hurricane Nora. NWS National Hurricane Center, Miami, FL

Redmond KT, Koch RW (1991) Surface climate and streamflow variability in the western United States and their relationship to large scale circulation indices. Water Resour Res 27(9):2381-2399

Rubin HJ, Rubin IS (1995) Qualitative interviewing: the art of hearing data. Sage Publications, Thousands Oaks, CA

Schoenberger E (1991) The corporate interview as a research method in economic geography. Prof Geogr 43(2):1991

Sonka ST, Changnon SA, Hofing SL (1992) How agribusiness uses climate predictions-implications for climate research and provision of predictions. Bull Am Meteorol Soc 73(12):1999-2008

Stern PC, Easterling WE (eds) (1999) Making climate forecasts matter. National Academy Press, Washington, DC

US Army Corps of Engineers, Los Angeles District (1994) Flood damage report State of Arizona: floods of 1993. US Army Corps of Engineers, Los Angeles

Waters SD (1997) Storm report: Tropical Storm Nora. Maricopa County Flood Control District. Phoenix, AZ. Also available at: http://156.42.96.39/alert/WY97/nora_rpt.pdf

Webb RH, Betancourt JL (1992) Climatic variability and flood frequency of the Santa Cruz River, Pima County, Arizona. Water Supply Paper 2379, US Geological Survey, Tucson, AZ

Whyte AVT (1977) Guidelines for field studies in environmental perception. United Nations Educational, Scientific and Cultural Organization, Paris

Woodhouse CA (1997) Winter climate and atmospheric circulation patterns in the Sonoran desert region, USA. Int J Climatol 17(8):859-874

Proofs received from author(s): August 1, 2001 